\title{
TUTELA ANTECIPADA E PEDIDO INCONTROVERSO À LUZ DA RAZOÁVEL DURAÇÃO DO PROCESSO
}

\author{
Alan Robson de Souza Gonçalves'
}

Resumo: $O$ presente artigo expõe a autonomia e características da antecipação de tutela decorrente da incontrovérsia de um ou mais pedidos, ou ainda, sobre parte do(s) pedido(s). Prossegue-se com a abordagem de pontos nodais que dão ensejo a diversas divergências sobre sua aplicação e natureza, tendo em vista os efeitos daí decorrentes. Por fim, busca-se pontuar o substancial peso do instituto frente o postulado constitucional que constituiu um dos maiores desafios da processualística contemporânea, qual seja, assegurar a razoável duração do processo.

Palavras-chave: Tutela antecipada. Pedido incontroverso. Devido processo legal. Razoável duração do processo.

\section{INTRODUÇÃO}

Muito se tem falado da necessidade de inovações processuais que venham dar efetividade ao princípio da razoável duração do processo, insculpido no inc. LXXVIII do art. 5o da Constituição da República Federativa do Brasil de 1988 (CRFB/88), fruto da Emenda Constitucional n. 45 (Reforma do Judiciário). Todavia, não raro, ignora-se a necessidade de paralelamente a este movimento de reformas processuais, aperfeiçoar

1 Bacharel em Direito pela Universidade do Vale do Itajaí (UNIVALI). Especialista em Direito Público pela FURB/ESMESC. Especialista em Prática Jurídica pela FURB/ ESMESC. Assessor Jurídico do Tribunal de Justiça de Santa Catarina. E-mail: alan.robson@tjsc.jus.br 
e/ou tornar mais eficiente meios já introduzidos em reformas anteriores. Exemplo disso é o instituto da antecipação de tutela na modalidade decorrente da incontrovérsia do pedido, tornada explicita com o advento da Lei n. 10.444/2002, ao acrescentar o $\S 6^{\circ}$ ao art. 273 do Código de Processo Civil (CPC).

Aludido instituto, demonstra a prática jurídica, não é usualmente utilizado, nada obstante se saber que ordinariamente se fazem presentes os pressupostos para tanto. Talvez este fenômeno seja decorrência das controvérsias que sempre circundaram o instituto, que vão desde a autonomia da aludida espécie de tutela, até a forma e efeitos de sua concessão. Todavia, tais circunstâncias não podem ter o condão de apequenar esta importantíssima inovação do processo civil brasileiro, pois "a tutela antecipatória do art. $273, \S 6^{\circ}$, é o único remédio capaz de evitar que o autor seja prejudicado, além da medida usual, pelo tempo de demora do processo" (MARINONI, 2002, p. 157). Conforme registra Doria (2003, p. 80), a observância de formalidades e procedimentos que acabe impondo às partes o ônus de aguardar o mesmo tempo para a apreciação das questões controvertidas e incontrovertidas, gera insatisfação e descrédito na jurisdição. Daí a necessidade de aprofundamento sobre esta superveniente hipótese legislativa de antecipação dos efeitos da tutela, pois consentânea com as aspirações não só da comunidade jurídica, mas também, e principalmente, da própria sociedade que aguarda por maior efetividade na prolação e cumprimento das decisões judiciais.

\section{MODALIDADE AUTÔNOMA}

Em consonância com o art. 273 do CPC, afora os casos decorrentes de obrigação de fazer e não fazer (art. 461, § 3º do $\mathrm{CPC}$ ), e alguns casos de procedimentos especiais regulados pelo CPC e legislação extravagante, no qual também há previsão específica do instituto, a antecipação dos efeitos da tutela encontra viabilidade em diversas situações base, a depender da combi- 
nação de seus pressupostos. Segundo Scarpinella (2010), seus pressupostos legais são de duas ordens: (i) necessários e (ii) cumulativo-alternativos. Em geral, seriam sempre necessárias a 'prova inequívoca' e a 'verossimilhança da alegação', presentes no caput do dispositivo. Seriam cumulativo-alternativos o 'receio de dano irreparável ou de difícil reparação’ e o abuso de direito de defesa ou manifesto propósito protelatório do réu, decorrentes, respectivamente, dos incisos I e II do próprio art. 273 do CPC.

Assim, estando presentes os pressupostos do caput do art. 273, a tutela poderá ser concedida caso também se faça presente ao menos um dos pressupostos cumulativo-alternativos.

Mas não é só. Existe ainda, a previsão da concessão da antecipação da tutela nos casos em que um dos pedidos se demonstre incontroverso, conforme $\S 6^{\circ}$ do dispositivo acima mencionado. Essa hipótese, conforme anota Scarpinella (2010, p. 31), "se distancia das exigências feitas pelo caput do art. 273, sendo suficiente para a antecipação dos efeitos da tutela jurisdicional que '... um ou mais dos pedidos cumulados, ou parcelas deles', mostre-se incontroverso". Portanto, configura pressuposto legal exclusivo dessa modalidade antecipatória ${ }^{2}$, que um ou mais dos pedidos, ou ainda, parcela de um dos pedidos, demonstre-se incontroversa. Também nesse sentido, Carneiro (2010, p. 43), asseverando que se trata de uma nova hipótese de antecipação, não devendo assim ser confundida com aquelas já previstas nos incisos I e II do art. 273. Não diferente é a posição de Marinoni (2002, p. 134), um dos processualistas que mais se ocupou do tema, quando deixa claro que a tutela do $\S 6^{\circ}$ não se confunde com a tutela decorrente do inc. I do art. 273, baseada exclusivamente em cognição sumária. Aliás, a própria topografia do artigo deixa claro tratar-se de nova hipótese de antecipação.

Em verdade, a essência da hipótese então positivada não conta com ares de inediatidade no processo civil. Como bem observado por Doria (2003, p. 83), o que se fez foi trazer ao

2 Muito embora seja corrente no meio jurídico a expressão antecipatória, DINARMARCO (2009, p. 280) a entende indevida, já que deveria ser utilizada apenas para as 'medidas' com que o juiz antecipa a tutela jurisdicional. 
processo de conhecimento aquilo que já era possível na fase executiva, ou seja, a satisfação da parte do crédito não impugnada, prosseguindo-se apenas quanto ao restante da pretensão.

\section{PEDIDO INCONTROVERSO}

Como visto, a antecipação de tutela decorrente da incontrovérsia do pedido (art. 273, § 6º do CPC) não é dependente dos requisitos do caput e incisos do dispositivo legal em que se insere. Mas ao menos em relação à verossimilhança da alegação, não é inteiramente correto se afirmar essa absoluta independência. Conforme pontua Vaz (2002, p. 126) "cuidou o legislador reformista, dentro de perspectiva da maior efetividade para o processo, de conceber uma espécie de tutela antecipada desvinculada, em princípio, dos requisitos básicos previstos para as demais espécies”. A ressalva 'em princípio', anota o autor, decorre da circunstância de que o exame da verossimilhança da alegação não resta de todo afastado. Isto porque, não obstante a incontrovérsia instalada autorizativa da concessão da tutela, não se dispensa o julgador de verificar se as consequências jurídicas aventadas pelo autor encontram substrato legal, já que a incontrovérsia reside sobre os fatos e não sobre o direito, o qual, salvo a hipótese prevista no art. 337 do CPC, independe de prova ( $\mathrm{da}$ mihi factum dabo tibi jus). No mesmo sentido Bedaque (2009, p. 361), o qual entende que a verossimilhança é indispensável.

Afinal, conforme anota Dinamarco (2009, p. 352), “о juiz está vinculado aos fatos narrados na petição inicial, não podendo decidir com fundamento em outros, mas é sempre livre para aplicar o direito conforme seu entendimento - porque iura novit curia". Assim, ainda que incontroverso um dos pleitos, ou uma parte deles, tal fato, por si só, não enseja a concessão da tutela, pois os fatos alegados, ainda que qualificados pela ausência de impugnação, podem não ensejar as consequências jurídicas que arregimentou o autor ao seu pedido, até porque, "a relevância jurídica dos fatos e suas consequências na esfera 
legal independem da conduta das partes, estão diretamente ligadas à decisão judicial" (DORIA, 2003, p. 94).

Nessa senda, Scarpinella registra que tecnicamente não é certo se falar em incontrovérsia do pedido, mas sim em incontrovérsia dos fatos a ele subjacentes, isto é, a causa de pedir. E para ilustrar a sua conclusão, exemplifica nos seguintes termos (2010, p. 112):

PC demanda APP pleiteando danos materiais e morais. Fundamenta seu pedido na existência de erro médico. Há dois pedidos - cumulação simples, mas uma só causa de pedir. A culpa (em sentido amplo) do médico, é que causou os danos que agora PC pleiteia perante o Estado-juiz. Se APP contestar o fato - não houve erro médico, porque seu agir não foi culposo em nenhuma modalidade -, não há como incidir o $\S 6^{\circ}$, ainda que APP, o réu, não impugne especificamente o pedido de dano moral. É importante destacar este ponto porque, uma vez impugnado um dos dois pedidos cumulados, nem por isso o juiz formará, em seu íntimo, convicção diferente com relação ao mesmo e único fato que fundamenta o pedido (a causa de pedir): ter, ou não, havido erro médico. [...] É sempre a incontrovérsia do fato que autoriza a antecipação dos efeitos da tutela jurisdicional com base no dispositivo em exame e não a 'incontrovérsia do pedido' propriamente dito.

Também atento a esta problemática, Vaz (2002, p. 128) pontua que a alusão legislativa a pedidos incontroversos, e não fatos foi proposital. Justamente porque há fatos que ainda que incontroversos, serão juridicamente irrelevantes, dada a ausência de substrato legal a lhe embasar, de modo que poderão não gerar o decreto de procedência, restando, portanto, inviável a aplicação da antecipação da tutela nos moldes delineados pelo $\S 6^{\circ}$ do art. 273 do CPC.

Acreditamos que a melhor técnica não foi observada pelo legislador, pois a incontrovérsia é mesmo afeta aos fatos, e não 
aos pedidos. Por isso é que ao réu incumbe o ônus da impugnação especificada dos fatos, e não dos pedidos (art. 302 do CPC). O mesmo ocorre com o a revelia. Faz incidir presunção de veracidade sobre os fatos (art. 319 do CPC), e não sobre os pedidos, o que, todavia, não irá acarretar a automática procedência destes, pois como cediço, a viabilidade da pretensão terá de ser igualmente aferida, quiça, submetida à dilação probatória (art. 324 do CPC).

Desta feita, o dispositivo deve ser entendido de modo que a incontrovérsia, na ausência de impugnação, instala-se apenas sobre os fatos, mas ainda que configurada, terá de se verificar a viabilidade jurídica da pretensão. Presente esta, a antecipação se tornará impositiva.

Apenas restará dispensada essa análise, quando o réu, além de tornar os fatos incontroversos, seja expressa ou tacitamente (art. 302 do CPC), reconhecer a procedência do pedido (art. 269, inc. II, do CPC). Afinal, em se tratando de direitos disponíveis, não caberá ao julgador impedir os efeitos decorrentes desse reconhecimento, e a procedência do que foi postulado, desde que presentes os pressupostos processuais e as condições da ação, será mesmo de rigor. "Quem admite a procedência do pedido impede que o juiz julgue, propriamente, o mérito, já que o processo deve ser encerrado com julgamento de mérito somente em virtude de o réu ter admitido que o autor tem razão" (MARINONI, 2002, p. 125). Não se deve nunca confundir a hipótese com a confissão e a ausência de contestação, onde o réu apenas aceita tacitamente os fatos, e não seus efeitos, como verdadeiros, o que, como visto, não implica necessariamente em procedência do pedido.

$\mathrm{Na}$ hipótese de reconhecimento do pedido, poderiam alguns questionar a utilidade da antecipação da tutela, já que a parte derrotada, acorde com o pedido julgado procedente, não teria interesse para recorrer (art. 499 do CPC). Todavia, ainda que o recurso interposto nesse sentido possa não ser recepcionado, fato é que, em sendo deferida a antecipação dos efeitos da 
tutela, a sentença terá efeitos imediatos, não sendo necessário sequer aguardar o inicio do decurso do prazo recursal. Assim, a antecipação decorrente da incontrovérsia trará muito mais eficácia à sentença prolatada em razão do reconhecimento do pedido, pois desde então poderá ensejar efeitos materiais.

Imprescindível atentar ainda ao fato de que a defesa apresentada pode ser indireta. Ou seja, admite o réu os fatos alegados, desincumbindo o autor do seu ônus probatório (art. 333. inc. I, do CPC), porém, opõe outro(s) fato(s), impeditivo(s), modificativo(s) ou extintivo(s) do direito pleiteado, chamando assim para si o ônus probatório, a rigor do inc. II do art. 333 do CPC. Nesta hipótese, conforme disciplina o art. 326 do CPC, necessária a oportunização de réplica, pois sobre os fatos alegados pelo réu (impeditivos, modificativos e extintivos), caberá o autor dizer, sob pena de incidir em seu desfavor o ônus da impugnação especificada. Essa circunstância não é prevista expressamente, porém é decorrente da interpretação sistêmica do código (arts. 302 c/c o 326 e 333). Nesse sentido, aliás, já pontuava Calmon de Passos (1983, p. 274), e continua sendo observada pela jurisprudência hodierna ${ }^{3}$.

Assim, apresentada a defesa indireta, vê-se que mesmo estando configurada a incontrovérsia dos fatos alegados na petição inicial, ou então, parte dos fatos atrelados a um dos pedidos, não será viável a antecipação de tutela com fulcro no $\S$ $6^{\circ}$ do art. 273do CPC, ainda que parcialmente.

Neste caso, defende Marinoni (2001, p. 247), até será possível a antecipação quando a chamada exceção substancial (fato impeditivo, modificativo ou extintivo) depender de

3 "Como regra, cabe ao autor a prova do fato constitutivo da pretensão deduzida, e ao réu, a prova do fato impeditivo, modificativo ou extintivo. Ocorrendo a réplica do artigo 326 do Código de Processo Civil, faz o autor as vezes de réu, cabendo-lhe impugnar os novos fatos impeditivos, modificativos ou extintivos da pretensão do demandante, trazidos na contestação. Se tal não ocorre, essa omissão traduz-se em confissão do autor, dispensado o réu de produzir prova a respeito, já que, sobre fatos incontroversos, não se faz prova, com a incidência do inciso III do artigo 334 do Código de Processo Civil" (TJSC, Ap. Cív. n. 2006.033934-9, de Blumenau, rel. Des. Jaime Luiz Vicari, j. Em 5.8.2010). 
prova e se mostrar provavelmente infundada. Assim, nos casos de "exceção substancial indireta provavelmente infundada", defende o sobredito autor ser viável a antecipação de modo a tornar equânime a distribuição do ônus decorrente da demora do processo, porém, não com fundamento no $\S 6^{\circ}$ do art. 273, mas sim no inc. II do art. 273 (abuso de defesa), ou seja, através de outra modalidade de antecipação dos efeitos da tutela, que não a decorrente da incontrovérsia.

Em caso de apresentação de contestação genérica, segundo Marinoni (2002, p. 119), o julgamento não deverá se dar em razão da revelia (art. 330, inc. II), mas sim, através de julgamento antecipado da lide decorrente da desnecessidade de continuação da dilação probatória (art. 330, inc. I). Na esteira do escólio do referido autor, não há que se falar em revelia em caso de contestação genérica, já que resposta foi apresentada. Todavia, nessa circunstância, o julgamento antecipado se torna possível tendo em vista a incidência do art. 302, caput, do CPC. Da mesma forma que a petição inicial não pode ser inepta, gerando a extinção sem resolução de mérito (art. 267, inc. I c/c o 295, inc. I) a resposta também tem que ser apta. A generalidade da contestação, contudo, é 'punida' com a aplicação do ônus da impugnação especificada. Porém, nesses casos, a sentença deverá prever a antecipação decorrente da incontrovérsia. Do contrário, estar-se-ia criando distinção para situações que reclamam identidade de providência, conforme se aborda no tópico dedicado à cumulação de pleitos.

\section{INCONTROVÉRSIA SOBRE PARTE DO PEDIDO}

Após apresentada resposta, a incontrovérsia pode surgir sobre apenas parte de um dos pedidos. Exemplo clássico seria a cobrança de uma determinada dívida de $\mathrm{R} \$$ 10.000,00 (dez mil reais), quando em contestação afirma o réu que diferentemente do alegado deve apenas $\mathrm{R} \$ 6.000,00$ (seis mil reais). Se para julgar a parte controvertida $(\mathrm{R} \$ 4.000,00)$ for necessária a 
instrução processual, nada justifica que o autor tenha de esperar o fim da instrução, e em havendo apelo, a ser ordinariamente recebido no duplo efeito (art. 520, caput, do CPC), esperar o julgamento do recurso, para só então ter início a execução, se de pronto resta reconhecida a sua condição de credor de pelo menos $60 \%$ (sessenta por cento) do crédito reclamado. Se assim ocorrer, ao demandado haverá uma situação muito cômoda, que será devedor confesso da maior parte do crédito, mas nada vai pagar até esgotar todos os meios processuais, postergando assim o cumprimento integral da obrigação até o final deslinde da lide.

A condição do autor, por sua vez, é proporcionalmente desfavorável, pois ou abre mão do crédito remanescente, ou de parte dele, em eventual composição, para poder desde já iniciar a execução, ou então continua discutindo, e neste interstício, vendo-se privado do bem da vida legitimamente pretendido. Essa situação deve ser evitada sob pena de desprestígio da justiça.

Portanto, nessa hipótese, incumbe ao magistrado desde logo lançar mão do valioso meio concedido pelo legislador ordinário, e deferir ao autor a antecipação da tutela sobre a parte incontroversa ( $\mathrm{R} \$ 6.000,00)$, a fim de neste tocante viabilizar desde já o cumprimento da obrigação.

Assim a demora do processo, que consubstancia o que Bedaque (2009, p. 362) chama de 'dano marginal', fica atrelada apenas a parte do pedido em que permanece a discussão, e se o intuito do réu era discutir apenas para atrasar o cumprimento da obrigação como um todo, certamente poderá restar desestimulado para tanto, já que parte do postulado será desde então disponibilizado ao autor, e o ganho decorrente do atraso no cumprimento integral da obrigação, quando sabedor o devedor da procedência também quanto à parte controvertida, frente o desgaste do processo, poderá não mais traduzir uma situação vantajosa tendo em vista o custo/benefício. $\mathrm{Na}$ linha do exposto por Marinoni (2002, p. 177), é preciso que o processo civil brasileiro deixe de ser um excelente investimento econômico para o réu que não tem razão. 
Anote-se que o $\S 6^{\circ}$ do art. 273 do CPC não faz qualquer limitação ao tipo de obrigação, de modo que, embora a obrigação de pagar quantia certa seja a mais profícua em ensejar situações de incontrovérsia parcial, obrigações de natureza diversa também podem comportar sua aplicação. Marinoni (2002, p. 109) cita, por exemplo, a situação em que alguém se obrigue a entregar 500 quilos de cimento em uma determinada obra, e ocorrido o inadimplemento, o credor postula a entrega da obra-prima e o devedor aduz que teria de entregar apenas 200 quilos, reconhecendo assim parcialmente a sua obrigação. Ainda na esteira do aludido autor, pode-se imaginar alguém que se obrigou a entregar dois objetos, e quando compelido pelo credor judicialmente alega que possui obrigação de entregar apenas um dos bens.

\section{SITUAÇÕES IMPEDITIVAS}

A incontrovérsia dos fatos subjacentes ao pedido pode se configurar por diferentes meios. Pode ser em decorrência da aplicação dos efeitos da revelia (art. 319), ou porque os fatos foram confessados pela parte contrária (art. 334, II), ou ainda, porque tornados incontroversos em decorrência da aplicação do ônus da impugnação especificada dos fatos constitutivos do direito autoral (arts. 302 e 333, I c/c 334, inc. III). Todavia, há exceções em que a despeito da ausência de contestação ou impugnação especificada, ou confissão, o fato não poderá ser tido por incontroverso de modo a justificar a antecipação decorrente do $\S 6^{\circ}$ do art. 273 do CPC.

Diz o art. 302, inc. I, do CPC, que ainda que não especificado, não se presume verdadeiro o fato se não for admissível a seu respeito a confissão. Por sua vez o art. 351 do CPC diz que não vale como confissão a admissão em juízo de fatos relativos a direitos indisponíveis. $\mathrm{O}$ art. 320 do mesmo diploma também impede que incida os efeitos da revelia quando o litígio versar sobre direitos indisponíveis. Portanto, essa é a primeira casuís- 
tica. Tratando-se de direitos indisponíveis, não caberá a antecipação decorrente da incontrovérsia dos fatos.

Também não incidirá o ônus da impugnação especificada, assim como os efeitos da revelia, quando a petição inicial não estiver acompanhada de instrumento público que a lei considera indispensável à prova do ato, conforme dispõem os arts. 302, inc. II e 320, inc. III, ambos do CPC.

$\mathrm{O}$ art. 302, parágrafo único, do CPC também dispõe que não se aplica o ônus da impugnação especificada ao defensor dativo, ao curador especial (art. 9º, incs. I e II), e ao Ministério Público. Assim, a negativa geral, nestes casos, será suficiente para manter com o autor o ônus da prova do fato constitutivo (art. 333, inc. I), sob pena de improcedência do pedido.

Cumpre observar que a aplicação da impugnação especificada tem que atender à razoabilidade. Assim, explicita o inc. III do art. 302, do CPC, que embora os fatos não tenham sido impugnados especificamente, o contexto geral da resposta pode deixar claro que foram impugnados. Ou seja, se numa demanda em que se pretende o ressarcimento por danos decorrente de acidente de trânsito, é certo que se o réu aventar a ausência de culpabilidade para a ocorrência do infortúnio, o pedido indenizatório de lucros cessantes não poderá ser tido por incontroverso tão somente porque o réu não se manifestou especificamente sobre este tópico.

O magistrado também deverá estar atento a hipótese em que a ausência de resposta, ou resposta evasiva, sem nada impugnar de fato, poderá ser fruto de colusão das partes, caso em que, ao invés de conceder a antecipação decorrente da incontrovérsia, deverá sim julgar o processo extinto sem resolução de mérito (art. 129 c/c 485, inc. III), sem prejuízo das penas aplicáveis.

Importa anotar, que conforme exposto por Figueira Júnior (2002, p. 95), as tratativas de propostas feitas pelo réu para fins de composição amigável do litígio, não podem ser levadas em conta pelo magistrado como reconhecimento tácito de parte do 
pedido de modo a viabilizar a antecipação dos efeitos da tutela por decorrência de suposta incontrovérsia. Afinal de contas, "se assim não for, toda e qualquer prática de negociação que não frutificar, terminará por acarretar ao réu (injusta e inexplicavelmente) o reconhecimento parcial do pedido relativo à parcela sobre a qual a proposta de acordo foi formulada (FIGUEIRA JR, 2002, p. 96).

Deve ainda se ter em mente situações em que, nada obstante configurada a incontrovérsia sobre os fatos, notadamente quando decorrente da ausência de resposta ou impugnação especificada, o juiz não estiver convencido sobre os pressupostos fáticos dos pedidos.

Nesse sentido, claro o art. 324 do CPC, que autoriza o juiz, mesmo quando verificada a revelia, e em tese, configurada a incontrovérsia sobre os fatos propulsores dos pedidos, determinar que o autor especifique as provas que efetivamente pretende produzir. Afinal, o juiz, detentor do livre convencimento motivado (art. 131 do CPC), não pode ser escravo da das regras procedimentais, e assim ter que julgar a lide de forma contrária ao seu convencimento. Até porque, a revelia, quando decorrente da ausência de resposta, e não resposta intempestiva, pode deixar dúvidas se a omissão do réu foi proposital. A obrigação das partes comparecerem em juízo, muitas vezes, não encontra eco na realidade social de nosso país ${ }^{4}$.

Todavia, parece-nos que havendo duvida, deverá o juiz expressar a circunstância, de modo a evidenciar que não obstante configurada a incontrovérsia sobre a causa de pedir, entende necessário naquele caso concreto maior dilação probatória. Trata-se de decorrência do dever de toda decisão judicial ser fundamentada (art. 93, inc. IX, da CRFB/88). O autor precisa ter ciência de que o juízo não está incorrendo em error in procedendo, mas sim, que, mesmo que formalmente tenha se configu-

\footnotetext{
4 Nesse sentido, há excelente abordagem de José Carlos Barbosa Moreira in Sobre a multiplicidade de perspectivas no estudo do processo. Revista Brasileira de Direito Processual Civil. São Paulo: RT, n. 56.
} 
rado a incontrovérsia sobre os pressupostos fáticos de seu pleito, o julgador não restou convencido, e que, portanto, inalterado o quadro processual, a improcedência será de rigor. Esta explicitação evitará dúvidas sobre o ônus probatório (art. 333, inc. I), pois, o autor, frente a incontrovérsia, poderia entender já ter se desincumbido desse mister, deixando, assim, de especificar provas e ser surpreendido com o resultado negativo.

\section{CUMULAÇÃO DE PEDIDOS}

Prefacialmente cumpre registrar que o imediato julgamento do pedido tornado incontroverso é uma decorrência da tentativa de se manter harmônico o sistema que admite sua cumulação, de modo que, veio em boa hora a explicitação da viabilidade da tutela decorrente $\S 6^{\circ}$ do art. 273 do CPC. "Perceba-se que o processo que admite a cumulação de pedidos mas não aceita a fragmentação de seu julgamento agrava a situação do autor, pois a demora necessária à averiguação do direito já é, por si só, fonte de prejuízo" (MARINONI, 2004, p. 347).

A aplicação da antecipação de tutela decorrente da incontrovérsia de um ou mais pedidos, ou ainda, de parte de algum ou alguns deles, precisa observar a forma em que se deu a cumulação desses pedidos. Conforme o art. 292 do CPC, a cumulação dos pedidos pode ser própria ou imprópria, ou seja, pode haver conexão entre os pleitos ou não. Todavia, os seguintes requisitos deverão ser observados: (i) que os pedidos sejam compatíveis entre si; (ii) que seja competente para conhecer deles o mesmo juízo; (iii) que seja adequado para todos o mesmo tipo de procedimento, a menos que não ocorrendo esta última hipótese, o autor empregue o procedimento ordinário para todos eles. Quanto ao primeiro requisito, anota Scarpinella (2010a, p. 113), que a compatibilidade é mais jurídica do que lógica. Isto porque, os pedidos podem ser incompatíveis ou inconciliáveis caso confrontados um com o outro. A rigor, pode-se dizer que os pedidos seriam ontologicamente incompatíveis, pois quem 
pretende rescindir, não pode pedir a redução de sua prestação contratual. Todavia, juridicamente tais cumulações são viáveis, já que além da cumulação simples, em que um pedido é completamente independente do outro, quando tiverem em comum apenas as partes, por exemplo, pode haver a cumulação sucessiva, subsidiária (art. 289 do CPC), ou ainda, alternativa (art. 288 do CPC).

Na cumulação sucessiva um pedido só poderá ser acolhido, caso o primeiro também o seja. Desta feita, o primeiro pedido é pressuposto para a acolhida do segundo. É o caso de pedido de declaração de inexistência de relação jurídica, e por decorrência, condenação pela inscrição indevida. De regra, o segundo pedido só será procedente quando acolhido o primeiro.

Quanto à cumulação subsidiária, o pedido formulado em segundo lugar só será apreciado na hipótese de o primeiro não poder ser acolhido. Ou seja, ao contrário do que ocorre com a cumulação sucessiva, o acolhimento do primeiro é prejudicial ao segundo. É o exemplo dado em que se pede a rescisão contratual, e quando não, a redução equitativa da prestação.

E por fim, a cumulação alternativa, decorre da própria natureza da obrigação, ou seja, quando o devedor puder cumprir a obrigação por mais de um modo, ex vi do art. 252 do Código Civil (CC/02).

Feitos estes apontamentos, cumpre anotar as decorrências para o instituto em apreço. Conforme anote Zavascki (2009, p. 113) "Se o pedido for sucessivo (ou, conforme diz a lei, 'em ordem sucessiva, a fim de que o juiz conheça do posterior, em não podendo acolher o anterior' - CPC, art. 289), só fará sentido antecipar os efeitos da tutela relativa ao pedido principal".

5 Correspondente ao que chamamos de pedido subsidiário, justamente para diferenciá-lo do pedido sucessivo. Nesse sentido, veja-se Scarpinella (2010a, p. 110): "Quanto o autor manifesta preferência a um dos pedidos, isto é, a um dos bens da vida ou das prestações a que pretende ver o réu condenado, a hipótese é de cumulação 'eventual' ou 'subsidiária', a qual se refere o art. 289, embora o dispositivo refira-se erradamente a cumulação 'sucessiva'”. 
Por conseguinte, sendo o pedido principal controverso, pontua Zavascki (2009, p. 113) não fará sentido se antecipar o subsidiário, a menos que se trate de efeitos idênticos aos que decorrem daquele.

Quanto aos pedidos alternativos, cumpre observar a quem cumpre a escolha, que ordinariamente cabe ao devedor, se outra coisa não se estipulou, conforme exegese do art. 252 do CC/02. Assim, "não bastará que o pedido seja incontroverso. Exigir-se-á incontrovérsia também sobre o incidente de escolha e a prestação escolhida” (Zavascki 2009, p. 113).

Observadas estas peculiaridades, decorrentes da espécie de cumulação, tem-se que ocorrendo a incontrovérsia sobre um dos pedidos, a antecipação é medida aconselhável. Do contrário, haveria um estímulo para que o autor ajuizasse diversas demandas em apartado, cada um com um pedido, a fim de que formada a incontrovérsia em alguma, obtivesse a antecipação.

Não havendo a cumulação de pedidos, e presente a incontrovérsia, incumbe ao magistrado sentenciar o feito, a teor do art. 330, inc. I c/c 334, incs. II e III, ambos do CPC. Todavia, ainda assim, deverá conceder na sentença a antecipação dos efeitos da tutela, com fulcro no $\S 6^{\circ}$ do art. 273 do CPC. Do contrário, o autor que postulasse um único pleito, seria tratado de forma desigual, pois estaria sujeito ao efeito suspensivo decorrente de eventual apelo (art. 520, caput), e não gozaria da eficácia imediata do decidido, tal como aproveitaria caso tivesse obtido tutela quanto ao incontroverso e a demanda tivesse prosseguimento para análise de pedido remanescente. Conforme registra o escólio de Vaz (2002, p. 128) "Não é razoável sonegar a antecipação de tutela ao autor que formula apenas um pedido, porque possível o julgamento antecipado da lide, quando se possibilita a concessão nas hipóteses de pedidos cumulados”. Não é por outra razão que Bedaque (2009, p. 363), diz que para conferir coerência ao sistema, o juiz sempre que julgar antecipadamente o feito em razão da revelia, deverá conceder a anteci- 
pação de seus efeitos na própria sentença, dotando-a assim de eficácia imediata.

\section{NATUREZA DA DECISÃO CONCESSIVA}

A decisão que concede a antecipação dos efeitos da tutela consiste em decisão interlocutória ou sentença? A interrogação que se faz é fruto das dissonâncias encontradas na doutrina que se ocupa do tema. Isto porque há vozes respeitáveis que afirmam que a incontrovérsia sobre determinado pedido autoriza o julgamento imediato e definitivo do mesmo, já que ao contrário do que ocorre com a tutela decorrente do inc. I do art. 273 do CPC (verossimilhança), o pedido seria apreciado de forma exauriente (incontrovérsia), nada obstante a disposição do instituto constar no artigo que trata da antecipação da tutela. Assim, a apreciação feita com base no $\S 6^{\circ}$ do art. 273 do CPC traduziria o julgamento de mérito de parte da lide, apto, portanto, caso não haja recurso, a fazer a coisa julgada material, prosseguimento a demanda apenas para o julgamento do restante, pois o ponto incontroverso não mais seria passivel de revisão.

Por todos, veja-se a posição de Scarpinella (2010, p. 108-109):

A questão, longe de ser meramente teórica, tem repercussões práticas importantes. Toda a dinâmica da 'antecipação da tutela, com base nesse $\S$ $6^{\circ}$ depende da escorreita identificação de sua natureza jurídica. Afinal, é um 'terceiro' tipo de tutela antecipada, ao lado da situação de dano iminente (inciso I) e do abuso de direito de defesa ou manifesto propósito protelatório do réu (inciso II), ou se trata, apenas e tão somente, de uma forma pela qual se dá inicio à 'execução' do julgado, mesmo que de parte daquilo sobre o que o autor requereu tutela jurisdicional?

Este curso acolhe a segunda das alternativas. $\mathrm{O} \S$ $6{ }^{\circ}$, não obstante integrar o art. 273 , não cuida, 
propriamente, da mesma tutela antecipada de que tratam os incisos I e II. [...]

O dispositivo, com efeito, vai além. Trata-se de um caso em que a tutela é antecipada e também é (ou, pelo menos tende a ser) 'definitiva' a não 'provisória' (v. n. 8.3 do Capítulo 1 da parte III do vol. 1). É essa a razão pela qual não há sentido em se aplicar, nesses casso, o disposto no $\S 4^{\circ}$ do art. 273 nem, tampouco, o entendimento de que o magistrado deve confirmar a decisão que entendeu pela necessidade da antecipação da tutela a final (art. $273, \S 5^{\circ}, \mathrm{c} / \mathrm{c}$ o art. 520, VII) como expõe o n. 5, 'infra'.

É importante destacar, por isso mesmo, que o $\S 6^{\circ}$ do art. 273 ocupa-se com uma técnica de desmembramento de pedidos cumulados ou de parcela deles, viabilizando o julgamento parcial do pedido (ou dos pedidos cumulados, consoante o caso) na medida em que o processo se desenvolve regularmente. É como se, naqueles casos em que o dispositivo se aplica, houvesse uma verdadeira cisão de pedidos cumulados ou de parte de um só pedido. O que já é passível de julgamento deve ser julgado de imediato e, nesse sentido, a tutela jurisdicional deve ser prestada; o que ainda não é, impõe o prosseguimento do processo para aquele fim com a realização da fase instrutória. A ‘antecipação’ dá-se justamente na possibilidade de separação entre pedidos cumulados ou de um só pedido que, de outro modo, seriam todos enfrentados de uma só vez e em uma única oportunidade pelo magistrado.

O entendimento predominante, todavia, é de que a decisão baseada no $\S 6^{\circ}$ do art. 273 do CPC, embora se trate de espécie distinta da tutela antecipada, não perde essa natureza, embora possua autonomia, por ser, conforme visto, desvinculada dos requisitos próprios das demais espécies. Assim, a tutela decorrente da incontrovérsia do pedido, ou parte deste, é concedida por decisão interlocutória, podendo ser revista até o fim 
do processo, pois como ocorre com as demais espécies de antecipação de tutela, mantém o caráter provisório até que confirmada pela sentença, só então, podendo a matéria decidida dar azo à formação da coisa julgada.

Do contrário, estar-se-ia autorizando, tal como, aliás, admite Scarpinella, a possibilidade de julgamento fracionado do mérito, rompendo-se com o dogma da unicidade do julgamento.

Nessa toada dispõe Dinamarco (2004, p. 671):

Diferente da divisão da sentença em capítulos é a cisão do julgamento, consistente em antecipar a decisão de alguma questão de mérito suscitada pelas partes, pronunciando-se o juiz sobre ela antes de proferir sentença. Essa prática é absolutamente contrária ao sistema, porque todas as questões relacionadas com o mérito devem ser julgadas em um ato só, como emerge do comando contido no art. 459 do Código de Processo Civil. É na sentença que o juiz acolhe ou rejeita, no todo ou em parte, o pedido formulado pelo autor (art. 459). Essa prática transgride também o disposto no art. 458, inc. II, do Código de Processo Civil, segundo o qual é na motivação da sentença que o juiz deve examinar as questões relativas ao meritum causae (supra nn. 1.223-1.224). Tal é o 'princípio da unidade da sentença', que só pode ser contrariado quando uma específica norma de direito o autorizar (Liebman).

A divergência, quer nos parecer, provém das raízes históricos do $\S 6^{\circ}$ do art. 273. Afinal, admite a exposição de motivos do anteprojeto n. 13, que antecedeu, portanto, o Projeto de Lei n. 3.476/00, que por sua vez, redundou na lei n. 10.444/02, alteradora do CPC, que:

É acrescentado, como $\S 6^{\circ}$, dispositivo sugerido por Luiz Guilherme Marinoni, que explicita a possibilidade de o juiz, nos casos em que uma parte do pedido ou dos pedidos se torne incontroversa, 
conceder desde logo a esse respeito a tutela antecipada. Essa sugestão apresenta-se consentânea com as preocupações de eficiência do 'novo' processo civil.

Porém o legislador ordinário, propositalmente ou não, deixou de atender a sugestão do doutrinador nos moldes que este efetivamente pretendia, pois pelo que se pode aquilatar, Marinoni (2002, p. 139) propunha viabilizar o julgamento definitivo do pedido incontroverso, ou de parte deste que restasse incontroversa, quebrando assim, com o dogma da unidade ou unicidade do julgamento, que como visto, até hoje prepondera soberano no ordenamento pátrio.

Para que não pairem dúvidas, veja-se a manifestação de Marinoni (2002, p. 139) a respeito:

Se um dos pedidos apresentados pelo autor está maduro para o julgamento, será porque diz respeito apenas a matéria de direito, seja porque independe de instrução dilatória, a necessidade, cada vez mais premente, de uma prestação jurisdicional célere, e efetiva, justifica a quebra do velho princípio da "unità e unicità della decisione".

Não atendido este viés pelo legislador, e isto se retira da própria exegese do $\S 6^{\circ}$, autorizou-se mesmo apenas a antecipação de tutela, com requisito mais simples e objetivo que o das demais modalidades, é verdade, já que em linhas gerais, basta a incontrovérsia do pedido, porém, ainda por decisão interlocutória de antecipação, e assim, provisória, passível de revisão.

Desta feita, persiste o dogma da unidade ou unicidade do julgamento de mérito, fortemente arraigado na tradição processualística brasileira, tanto é, que mesmo ações autônomas, se conexas, preferencialmente devem ter julgamento simultâneo (art. 105 do CPC). E a tutela decorrente da incontrovérsia do pedido, não traduz julgamento de uma parte da demanda, a qual será julgada integralmente ao final por sentença única, mas sim decisão interlocutória, que embora baseada em elementos 
de convicção muito mais robustos do que aqueles próprios do juízo de verossimilhança, também é provisória, submetendo-se no restante, portanto, ao mesmo regramento previsto para as demais modalidades antecipatórias existentes.

E isto é admitido pelo próprio inspirador da alteração legislativa:

É preciso deixar claro que a tutela antecipatória, na presente hipótese, funda-se em 'cognição exauriente', e assim, em tese, poderia produzir 'coisa julgada material. Acontece que o legislador da "2a etapa da reforma do CPC", por razões de política legislativa, resolveu enquadrar a presente tutela na moldura do art. 273, deixando de modificar o seu $\S 4$, que deixa patente a sua natureza "provisória" e, assim, suscetível de revogação. Porém, o fato de uma decisão não produzir coisa julgada material não tem a ver com a cognição que lhe é inerente. Em outros termos: não é porque a decisão não produz coisa julgada material que ela é fundada em cognição sumária (MARINONI, 2002, p. 139-140).

Para Carneiro (2010, p. 47), a tese de que a decisão trataria de uma verdadeira sentença parcial, é passível de amplo debate doutrinário, todavia, difícil de aceitação frente o legislado. Não divergindo, Zavascki (2009, p. 113) afirma que embora talvez a melhor solução tivesse sido mesmo a possibilidade de cisão do julgamento, permitindo sentença parcial definitiva, não foi essa a opção do legislador, que preferiu o caminho da antecipação provisória.

Entendemos com aqueles que pensão que oportunizar que essa apreciação se dê apenas de forma provisória, é a melhor opção. Não se olvida que seja sedutor o argumento de que se um único pedido se torna incontroverso, por revelia, por exemplo, autoriza-se o julgamento definitivo, por sentença (art. 330, inc. II), razões não haveriam para que o pedido incontroverso também assim o fosse, prosseguindo a demanda apenas para viabilizar a instrução em relação ao pedido(s) remanescente(s). 
Ocorre que, ao fim, em termos práticos, a forma instituída pelo legislador é mais vantajosa.

Afinal, para o autor que tem razão quanto ao direito vindicado, e na forma do $\S 6^{\circ}$ do art. 273 do CPC tem o bem da vida pretendido em um dos pedidos já a sua disposição, pouco importa se o foi por tutela antecipada ou julgamento definitivo. Estará, de qualquer forma, com a possibilidade de poder usufruir o bem. Até porque, se possui razão, ao final a tutela será confirmada.

Por outro vértice, possuindo a decisão cunho provisório, evita-se o seguinte constrangimento: determinado pedido resta incontroverso, seja em razão da intempestividade da resposta apresentada, ou da deficiente impugnação dos fatos constitutivos, e sendo o direito pleiteado verossímil, o juiz concede a tutela, forte no $\S 6^{\circ}$ do art. 273 do CPC. Todavia, instruída a demanda para análise do pedido remanescente, acaba-se por constatar que o autor, em verdade, não faz jus a procedência de nenhum dos pleitos, inclusive, o já antecipado. Nesse caso, em razão da opção legislativa, ainda é possível ao magistrado julgar improcedentes os pedidos e revogar a decisão antecipatória retornando os litigantes ao status quo. Do contrário, a sentença poderia gerar descrédito, pois evidenciada a ausência do direito do autor, este seria privilegiado com a procedência de um dos pedidos, apenas por uma questão de desídia processual do réu, ainda que a verdade dos fatos viesse à tona com a instrução.

Esse é o entendimento de Bedaque (2009, p. 362), o qual consignou que em reflexão mais profunda, a opção legal the parece a mais adequada, pois produz os efeitos práticos pretendidos, sem retirar do juiz a possibilidade de revogar a tutela, quando concluir ao final do processo, pela inexistência do direito, mesmo em relação à parte incontroversa.

É bem verdade, que conforme substancioso argumento de Scarpinella (2010, p. 110), a não se reconhecer o $\S 6^{\circ}$ como possibilidade de desmembramento à fragmentação do julgamento, "o dispositivo teria sua incidência bastante apeque- 
nada porque sua função seria, toda ela, extraível do inciso II do art. 273, consoante a formulação original de Marinoni”. Afinal, antes da introdução do $\S 6^{\circ}$ ao art. 273 do CPC pela Lei 10.444/02, Marinoni (2004, p. 248) já defendida que "o réu que não contesta ou reconhece parcela do pedido e nada faz para adimplir a sua obrigação, limitando-se a conduzir o processo para a instrução, abusa do seu direito de defesa, pois protela a realização de direitos não mais controvertidos”. Sendo assim, já seria viável a antecipação com base no inc. II do art. 273 do CPC, ou seja, decorrente abuso do direito de defesa.

Todavia, parece que o mérito maior da introdução do $\S 6^{\circ}$ foi o de explicitar essa possibilidade. Afinal, a construção doutrinária de outrora - concessão de tutela do pedido incontroverso com base no abuso do direito de defesa - não era uníssona, e como todo entendimento, passível de inúmeras controvérsias e questionamentos. A partir da edição da Lei 10.444/02, não restou mais espaço para dúvidas quando a aplicabilidade dessa espécie, expressamente positivada (art. 273, § 6º do CPC) no sentido de que sempre viável quando se configurar controvérsia sobre um ou mais pedidos, ou sobre parte de um determinado pedido. Conforme Carreira Alvim (2006, p. 128), a antecipação da tutela quando ao incontroverso nunca foi vedada, mas havia um certo acanhamento da doutrina e da jurisprudência no admiti-la.

Ainda assim, mesmo diante desta explicitação legislativa, e passados quase dez anos do seu advento, a tutela antecipada decorrente da incontrovérsia parece não estar sendo aplicada em conformidade com toda a sua potencialidade, ao menos, essa é a impressão que se obtém em pesquisas jurisprudenciais.

\section{FUNDAMENTO CONSTITUCIONAL}

Um dos desafios que sempre foi imposto ao Estado Democrático de Direito foi o de tentar conciliar duas necessidades naturalmente inconciliáveis. A primeira é a de o Estado- 
-Juiz tentar apurar a verdade dos fatos, o que se dá através do processo, iniciando-se pela fase postulatória, seguida da instrutória, que pode ser extremamente simples ou complexa, e nesta última hipótese, prolongada, para só então se poder decidir (fase decisória). A segunda é a necessidade de que os jurisdicionados em geral, e especificamente os litigantes de cada causa, tenham uma resposta jurisdicional dentro de um prazo razoável, sob pena de nada ou pouco valer o direito reconhecido. "Assim, o jurista tem o dever de buscar soluções para que possam ser eliminados, ao menos, em parte, os males acarretados pela demora do processo, sabido que, como dizia Carnelutti, processo é vida" (MARINONI, 2002, p. 102). Afinal, exercer a jurisdição, conforme clássica lição, é dizer o direito do caso concreto, e o tempo é inimigo direto da eficácia da resposta jurisdicional, e assim, da credibilidade da própria justiça.

Atento a esta celeuma, é que o legislador, inspirado pelo autor Marinoni, incrementou o instituto da antecipação da tutela, outorgando-lhe modalidade oriunda da incontrovérsia do pedido ou parte deste, justamente para evitar que o dano decorrente da demora processual alcance também aquela parte da demanda que não mais precisa esperar pela instrução processual. O dano, assim, é evitado, porque a parte incontroversa, decidida, então, já ao fim da fase postulatória, possui efeitos imediatos, dada sua natureza antecipatória, muito embora, a opção legislativa tenha sido de apenas possibilitar o julgamento provisório desta parte incontroversa, já que passível de revisão quando do efetivo e único julgamento definitivo da lide.

Porém, ainda que decidido de forma provisória, justificável a concessão antecipatória, pois se é possível a antecipação dos efeitos da tutela apenas por um juizo de verossimilhança (art. 273, inc. I), muito mais o será frente a um contexto de incontrovérsia sobre determinado ponto.

Persiste, portanto, a ausência de certeza sobre o que foi antecipado, porém, como já asseverava Marinoni (1995, p. 63), há mais de uma década e meia, "A crise da justiça civil está aos 
olhos de todos; é preciso que os tribunais aceitem a obviedade que não pode haver efetividade sem riscos", ainda mais, quando esse risco é consideravelmente menor, como no caso do $\S 6^{\circ}$ do art. 273 do CPC, já que decorrente da inércia do réu em se contrapor devidamente ao alegado.

Assim, ainda que não presente o perigo de dano irreparável ou de difícil reparação, o direito tornado evidente, sobre determinado(s) pedido(s), ou parte deste(s), deve(m) ser prontamente atendido(s), justamente com o desiderato de dar uma resposta jurisdicional tempestiva, evitando a pontual desnecessidade de dano decorrente da demora do processo. "Se o direito à tempestividade da tutela jurisdicional é corolário do direito de acesso à justiça e é, portanto, garantido constitucionalmente, o processo civil deve estar predisposto de modo a possibilitar a realização plena e concreta (e não apenas formal deste direito)" (MARINONI, 2002, p. 156).

Por conseguinte, independentemente da urgência do caso concreto (para os quais há remédios outros, tais como o tutela antecipada decorrente do inc. I do art. 273, do $\S 3^{\circ}$ do art. 461, do art. $\S 3^{\circ}$ do art. 461-A, todos do CPC, do $\S 3^{\circ}$ do art. 84 do $\mathrm{CDC}$, as medidas cautelares, as liminares decorrentes dos procedimentos especiais, o poder geral de cautela - 798 do CPC), o direito a uma resposta jurisdicional em tempo razoável é uma decorrência natural da ordem constitucional. "Como é sabido, o art. $5^{\circ}, \mathrm{XXXV}$, da $\mathrm{CF}$, não só garante o direito de acesso à justiça, mas igualmente o direito à efetividade e à tempestividade da tutela jurisdicional" (MARINONI, 2002, P. 158). E o devido processo legal, franqueado a ambos os litigantes (art. $5^{\circ}$, LV, da CRFB/88), sob o viés de quem postula e possui o direito, só será efetivo quando atendidas suas expectativas ordinárias. Nesse sentido, pertinente a lição de Silva (1993, p. 154):

O 'devido processo legal' é um privilégio processual reconhecido apenas aos demandados? $\mathrm{Ou}$, ao contrário, também os autores terão direito a um processo igualmente 'devido', capaz de assegurar- 
- thes a real e efetiva realização prática - não apenas teórica - de suas pretensões? Um processo capenga, interminável em sua exasperante morosidade, deve ser reconhecido como um 'devido processo legal', ao autor que somente depois de vários anos logre uma sentença favorável, enquanto se assegura ao réu, sem direito nem mesmo verossímil, que demanda em procedimento ordinário, o 'devido processo legal', com plenitude de defesa?

Essas formulações, agora foram erigidas com a EC. $n$. 45 a uma garantia fundamental expresso, nos termos do inc. LXXVIII do art. 50 da CRFB/88, de modo que, "a todos, no âmbito judicial e administrativo, são assegurados a razoável duração do processo e os meios que garantem a celeridade de sua tramitação". Portanto, atualmente tornou-se ainda mais evidente e inquestionável a conformação da antecipação dos efeitos da tutela nos casos de configuração de incontrovérsia do pedido (ou parte deste) com a ordem constitucional vigente.

Desta feita, a nova espécie de antecipação, "representa simplesmente uma ação afirmativa em benefício do princípio constitucional da efetividade e, mais especificamente, do direito fundamental explicitado no art. 5, LXXVIII, da Constituição” (ZAVASCKI, 2010, p. 110).

\section{CONCLUSÃO}

O direito processual, na condição de ramo autônomo da Ciência Jurídica, meio próprio para a resolução das lides que não encontraram solução através dos meios pré-processuais, está sempre evoluindo para melhor atender as expectativas a que se proponha, qual seja a escorreita aplicação jurisdicional do direito material ao caso concreto. A tutela antecipada decorrente da incontrovérsia de um ou mais pedidos, ou sobre parte deles, vai além, pois disponibiliza ao juiz modalidade antecipatória que lhe possibilita assegurar desde logo o bem da vida pretendido, evitando-se, com isso, o dano marginal sobre parte 
desnecessária da lide. Essa prescindibilidade decorre, como visto, não só da incontrovérsia formada sobre o pedido ou parte deste, mas também do convencimento gerado pelo quadro ao magistrado.

Pode-se assim dizer que a tutela antecipada na hipótese do $\S 6^{\circ}$ do art. 273 do CPC traduz instrumento de aperfeiçoamento da efetividade do processo, atendendo, portanto, aos anseios da razoável duração deste. A ordem constitucional vigente não mais se conforma com o devido processo legal consubstanciado somente na observância do contraditório, ampla defesa, juiz natural, e outras dessas garantias processuais. A efetividade da prestação jurisdicional integra os pressupostos de observância do 'devido processo legal'. O processo tem que a um só tempo, assegurar a amplitude da defesa, mas também, o atendimento em tempo razoável das expectativas do autor que tem direito. A tutela antecipada, como já há muito pontua a doutrina, vem justamente para equalizar estes interessantes procedendo a distribuição do ônus do tempo do processo. Por este viés, a tutela decorrente do direito tornado evidente, encontra fundamento inquestionável, já que se possível a antecipação baseada em verossimilhança, muito mais quando fulcrada na incontrovérsia, onde a probabilidade de erro é significativamente reduzida.

Assim, conclui-se que a tutela antecipada decorrente do $\S 6^{\circ}$ do art. 273 do CPC, conforma-se com perfeição à Constituição Federal, pois ao mesmo tempo em que viabiliza a observância da garantia da razoável duração do processo (art. $5^{\circ}$, inc. LXXVIII, da CRFB/88), não desnatura qualquer garantia da parte contrária, já que baseada em pressupostos razoáveis, e ainda assim, passível de revisão quando do julgamento definitivo da lide.

Abstract: This paper presents the autonomy and the characteristics of the anticipation of guardianship resulting from the uncontroversial of 
one or more requirements, or even, of part(s) of the requirement(s). The approach of nodal points is carried on, giving rise to various disagreements over its application and nature, bearing in mind the resulting effects. Finally, there has been attempted to point out the substantial weight of the institute in relation to the constitutional postulate consistently one of the greatest challenges of contemporary proceduralistic, namely, to ensure a reasonable duration of the process.

Keywords: Anticipation of guardianship. Uncontroversial requirement. Due process of law. Reasonable duration of the process.

\section{REFERÊNCIAS}

BEDAQUE. José Roberto dos Santos. Tutela cautelar e tutela antecipada: tutelas sumárias e de urgência (tentativa de sistematização). 5ª ed. São Paulo: Malheiros, 2009.

CARNEIRO. Athos Gusmão. Da antecipação de tutela. Rio de Janeiro: Forense, 2010.

CARREIRA ALVIM. J. E. Tutela antecipada. 5ª ed. Curitiba: Juruá, 2006.

DINAMARCO. Cândido Rangel. Vocabulário do processo civil. São Paulo: Malheiros, 2009.

; Instituições de direito processual civil. $4^{a}$ ed. Vol. III. São Paulo:

Malheiros, 2004.

DÓRIA. Rogéria Dotti. A tutela antecipada em relação a parte incontroversa da demanda. São Paulo: Revista dos Tribunais, 2003.

FIGUEIRA JR. Joel Dias. Comentários à novíssima reforma do CPC. Rio de Janeiro: Forense, 2002.

MARINONI, Luiz Guilherme. A antecipação da tutela. São Paulo: Malheiros, 2004.

; Tutela antecipatória e julgamento antecipado: parte incontroversa da demanda. 5a ed. São Paulo: Revista dos Tribunais, 2002. 
; ARENHART. Sérgio Cruz. Manual do processo de conhecimento: a tutela jurisdicional através do processo de conhecimento. São Paulo: Revista dos Tribunais, 2001.

MOREIRA. José Carlos Barbosa. Sobre a multiplicidade de perspectivas no estudo do processo. Revista Brasileira de Direito Processual Civil. São Paulo: RT, n. 56.

PASSOS, José Joaquim Calmon. Comentários ao código de processo civil. Vol. III. Rio de Janeiro. Forense, 1983.

SCARPINELLA BUENO, Cássio. Curso sistematizado de direito processual civil 4: tutela antecipada, tutela cautelar, procedimentos cautelares específicos. 2 ed. São Paulo: Saraiva, 2010.

; Curso sistematizado de direito processual civil: procedimento comum :

ordinário e sumário, 2. tomo I. 3a ed. São Paulo: Saraiva, 2010a.

SILVA, Ovídio Baptista. A 'plenitude de defesa' no processo civil. In: TEIXEIRA. Sálvio de Figueiredo (Coord.). As garantias do cidadão na justiça. São Paulo: Saraiva, 1993.

VAZ, Paulo Afonso Brum. Manual da tutela antecipada: doutrina e jurisprudência. Porto Alegre: Livraria do Advogado. 2002.

ZAVASCKI. Teori Albino. $7^{\text {a }}$ ed. Antecipação da tutela. São Paulo: Saraiva, 2009. 